\title{
EFFECT OF PHOSPHORUS FERTILIZATION AND FRUIT THINNING ON SEED PRODUCTION OF SUMMER SQUASH PLANTS \\ 1-VEGETATIVE TRAITS AND LEAVES CHLOROPHYLL CONSTITUENT \\ Tartoura, E. A. A ${ }^{1}$; E. I. El - Gamily ${ }^{1}$; Y. B. A. EI - Waraky ${ }^{2}$ and Mariam.K.Y. kamel ${ }^{2}$ \\ ${ }^{1}$ Veg. and Flori. Dept. Fac. Agric., Mansoura. Univ. \\ Veg. Res. Dept., Hort. Res. Inst., Agric. Res. Center, Giza.
}

\begin{abstract}
This study was carried out during two summer seasons of 2012 and 2013 at Sakha Horticultural Research Station Farm, Kafr El-Sheikh Governorate, on summer squash (Cucurbita pepo L.) Eskandarani cultivar to study the impact of phosphorus fertilizer levels 20,40, 60 and $80 \mathrm{~kg} \mathrm{P}_{2} \mathrm{O}_{5}$ /fed. and fruit thinning treatments;i.e., without thinning (control), thinning the first fruit, thinning all fruits except the first and second ones and thinning the first and second fruit and their interaction on vegetative parameters and leaf chlorophyll contents.

Results indicated that, the highest values of vegetative characters; i.e., stem length, plant fresh and dry weight, leaf area/plant and chlorophyll content in leaves in both seasons were recorded when plants fertilized with $80 \mathrm{~kg} \mathrm{P}_{2} \mathrm{O}_{5} / \mathrm{fed}$. Number of leaves/plant not affected by phosphorus fertilizer levels, in both seasons. Thinning the first and second fruit produced the highest values of stem length, plant fresh and dry weight, number of leaves/plant, leaf area/plant and chlorophyll content in leaves in both seasons. On the other hand, squash plants fertilized with $80 \mathrm{~kg} \mathrm{P}_{2} \mathrm{O}_{5} / \mathrm{fed}$. with thinning the first and second fruit produced the highest values of stem length, plant fresh and dry weight, number of leaves/plant, leaf area/plant and chlorophyll content in leaves, while, squash plants fertilized by $20 \mathrm{~kg} \mathrm{P}_{2} \mathrm{O}_{5}$ /fed. with thinning all fruits except the first and second ones produced the lowest value of each character.

According to the mentioned results, the best results of both vegetative growth parameters and chlorophyll contents in leaves were recorded when squash plants fertilized by $80 \mathrm{~kg} \mathrm{P}_{2} \mathrm{O}_{5} / \mathrm{fed}$. with thinning the first and second fruit, therefore, this treatment could be recommended for improving squash plants performance under similar condition of this study.

Keywords: Cucurbita pepo, phosphorus fertilizer, fruit thinning, vegetative growth and chlorophyll contents .
\end{abstract}

\section{INTRODUCTION}

Summer squash (Cucurbita pepo L.), is one of the most important crop of the family cucurbitaceae, and of highly polymorphic vegetable grown during summer in tropical and subtropical condition. Phosphorus is a naturally occurring element that can be found in the earth's crust, water, and all living organisms. Phosphorus is one of 16 elements that are essential for plant growth and genetic material of all cells (DNA and RNA) (Starnes et al., 2008). As well as phosphorus is essential for a number of physiological functions that are involved with energy transformations. Phosphorus is a component of many cell constituents and plays a major role in several key 
processes, including photosynthesis, respiration, energy storage and transfer, cell division, and cell enlargement. Adequate phosphorus is needed for the promotion of early root formation and growth, also it improves crop quality and is necessary for seed formation (Mulins, 2009). Research has documented that applying fertilizer phosphorus increases crop growth and yields on soils that are naturally low in phosphorus and in soils that have been depleted through crop removal. Crop fertilization represents the greatest use of phosphorus in agriculture today.

Fruit thinning is defined as the removal of certain flowers or small fruits after fruit set therefore, some growers tend to pick some of early fruit for fresh market and leave the others to improve fruit yield, quality and seed production (Metwally, 1980).

Hence, the objective of this work was to study the effect of phosphorus fertilizers and fruit thinning treatments on vegetative growth parameters and chlorophyll contents in leaves of summer squash plants.

\section{MATERIALS AND METHODS}

This work was carried out at Sakha Horticultural Research Station, Farm during two summer seasons of 2012 and 2013, on summer squash (Cucurbita pepo L.) Eskandarani cultivar to study the impact of phosphorus fertilizer levels and fruit thinning treatments and their interactions, on vegetative parameters and leaf chlorophyll contents.

Soil samples were taken before sowing from a depth of $0-30 \mathrm{~cm}$ in both seasons for mechanical and chemical analysis. Mechanical analysis was determined as follow:

1- E.C ( $\mathrm{dS} \mathrm{m}^{-1}$ ) and soluble cations and anions ( meq/L). They were determined in soil-water extract (1:5) according to Page et al., (1982).

2- Soil reaction $(\mathrm{pH})$ : It was determined in soil. Water suspension $(1: 2.5)$ by compound electrode $\mathrm{pH}$ meter PT1-9 according to Cottenie et al., (1982).

3- Organic matter (\%). It was estimated by the rapid method of titration according to Black (1965)

4- $\quad$ Available N, P and K (ppm) were determined according to Jackson (1967).

The obtained soil data are presented in Table (1).

The experimental design was split-plot system in a randomized complete block design with three replicates. Four phosphorus fertilizer levels; i.e., 20, 40, 60 and $80 \mathrm{~kg} \mathrm{P}_{2} \mathrm{O}_{5}$ /fed. were assigned to the main plots. Phosphorus fertilizer, in the form of calcium super phosphate $\left(15.5 \% \mathrm{P}_{2} \mathrm{O}_{5}\right)$ was applied to the soil as one dose before sowing. The four fruit thinning treatments; i.e., control (without thinning), thinning the first fruit (Th.1), thinning all fruits except the first and second ones (Th.2) and thinning the first and second fruit (Th.3) were assigned as the sub plots. Fruit thinning treatments were carried out in each sub-plot and started from $5^{\text {th }}$ May to $11^{\text {th }}$ May in both seasons. 
This experiment included 16 different treatment combinations, each plot was comprised of four ridges $3.75 \mathrm{~m}$ length, $1 \mathrm{~m}$ width, the sub plot area was $15 \mathrm{~m}^{2}$. Seeds were sown on $11^{\text {th }}$ March in both seasons, normal cultural practices for the commercial summer squash production were followed according to the instructions advised by the Ministry of Agricultural.

Table(1):Mechanical and chemical soil characteristics at the experimental sites during the two growing seasons of 2012 and 2013.

\begin{tabular}{|c|c|c|c|c|c|}
\hline \multirow{2}{*}{\multicolumn{2}{|c|}{ Soil analysis }} & \multicolumn{2}{|c|}{2012 season } & \multicolumn{2}{|c|}{2013 season } \\
\hline & & $0-15 \mathrm{~cm}$ & $15-30 \mathrm{~cm}$ & $0-15 \mathrm{~cm}$ & $15-30 \mathrm{~cm}$ \\
\hline \multicolumn{6}{|c|}{ A: Mechanical analysis } \\
\hline \multicolumn{2}{|c|}{ Sand $(\%)$} & 12.44 & 5.92 & 12.44 & 5.92 \\
\hline \multicolumn{2}{|l|}{ Silt (\%) } & 23.95 & 34.77 & 23.95 & 34.77 \\
\hline \multicolumn{2}{|l|}{ Clay $(\%)$} & 60.52 & 59.48 & 60.52 & 59.48 \\
\hline \multicolumn{2}{|c|}{ Texture } & Clayey & Clayey & Clayey & Clayey \\
\hline \multicolumn{6}{|c|}{ B: Chemical analysis } \\
\hline \multicolumn{2}{|c|}{ Organic matter (\%) } & 1.16 & 1.03 & 1.28 & 1.10 \\
\hline \multicolumn{2}{|c|}{ Total N (\%) } & 0.101 & 0.091 & 0.105 & 0.093 \\
\hline \multicolumn{2}{|c|}{ Total carbonate (\%) } & 3.95 & 3.90 & 4.01 & 3.98 \\
\hline \multicolumn{2}{|c|}{ C.E.C (meq $/ 100 \mathrm{~g}$ soil) } & 32.00 & 30.00 & 31.60 & 29.80 \\
\hline \multicolumn{2}{|c|}{$\mathrm{SP}(\%)$} & 78.00 & 79.00 & 77.50 & 78.30 \\
\hline \multicolumn{2}{|l|}{ SAR } & 3.19 & 3.51 & 3.86 & 3.85 \\
\hline \multirow{3}{*}{$\begin{array}{l}\text { Available } \\
\text { (mg/kg soil) }\end{array}$} & $\mathrm{N}$ & 28.00 & 20.00 & 25.50 & 20.10 \\
\hline & $\mathrm{P}$ & 8.00 & 6.00 & 8.80 & 7.30 \\
\hline & K & 288.6 & 218.4 & 395.0 & 380.0 \\
\hline \multirow{4}{*}{$\begin{array}{l}\text { Soluble } \\
\text { cations } \\
\text { (meq/L) }\end{array}$} & $\mathrm{Ca}^{++}$ & 7.70 & 6.25 & 4.29 & 1.47 \\
\hline & $\mathrm{Mg}^{++}$ & 6.13 & 6.05 & 3.40 & 2.00 \\
\hline & $\mathrm{Na}^{+}$ & 8.40 & 8.70 & 5.60 & 5.08 \\
\hline & $\mathrm{K}^{+}$ & 0.21 & 0.20 & 0.32 & 0.78 \\
\hline \multirow{4}{*}{$\begin{array}{l}\text { Soluble } \\
\text { anions } \\
\text { (meq/L) }\end{array}$} & $\mathrm{CO}_{3}^{--}$ & - & - & - & - \\
\hline & $\mathrm{HCO}_{3}^{-}$ & 4.50 & 3.00 & 5.94 & 4.06 \\
\hline & $\mathrm{Cl}^{-}$ & 9.12 & 8.16 & 3.15 & 1.15 \\
\hline & $\mathrm{SO}_{4}$ & 8.82 & 10.04 & 3.52 & 4.12 \\
\hline \multicolumn{2}{|l|}{$\mathrm{pH}$} & 7.95 & 8.01 & 7.82 & 7.90 \\
\hline \multicolumn{2}{|l|}{$\mathrm{E} . \mathrm{C}(\mathrm{dS} / \mathrm{m})$} & 2.24 & 2.12 & 1.26 & 0.93 \\
\hline
\end{tabular}

* Soil and Water Analysis Institute, Sakha Lab., Agricultural Research Center (ARC).

\section{Data recorded:}

Growth parameters:

A random sample of five plants were taken from each plot at 70 days after sowing in both seasons of the study for measuring the vegetative parameters of summer squash plants, i.e., stem length $(\mathrm{cm})$, plant fresh and dry weight $(\mathrm{g})$, number of leaves/plant, Leaf area/plant $\left(\mathrm{cm}^{2}\right)$ was calculated according to Koller (1972). The leaf pigments (total chlorophyll content) of the fifth leaf from the growing tip of plant were estimated by spectrocolorimeter as described by Moran and Porath (1982). The concentration of total chlorophyll was calculated by substituting the reading in the following equations:

T.Chl. $=(7.04$ A664) $+($ 20.27A647) . 
The results of chlorophylls content were expressed in $\mathrm{mg} / \mathrm{cm}^{2}$.

\section{Weather data:}

Monthly average maximum (day) and minimum (night) air temperature as well as relative humidity in North Delta area of the two seasons were recorded according to the data of weather station as shown in Table (2) .

Table 2: *Maximum and minimum monthly temperature $\left({ }^{\circ} \mathrm{C}\right)$ and relative humidity $(\%)$ at the experimental site during the two growing seasons.

\begin{tabular}{|l|c|c|c|c|c|c|c|c|}
\hline \multirow{3}{*}{ Month } & \multicolumn{3}{|c|}{ Temperature (C) } & \multicolumn{3}{c|}{ Relative humidity (\%) } \\
\cline { 2 - 9 } & \multicolumn{2}{|c|}{$\mathbf{2 0 1 2}$} & \multicolumn{2}{c|}{$\mathbf{2 0 1 3}$} & \multicolumn{2}{c|}{$\mathbf{2 0 1 2}$} & \multicolumn{2}{c|}{ 2013 } \\
\cline { 2 - 9 } & Max. & Min. & Max. & Min. & Max. & Min. & Max. & Min. \\
\hline March & 25.9 & 15.9 & 26.6 & 16.9 & 85.5 & 39.7 & 85.0 & 41.0 \\
\hline April & 30.9 & 19.4 & 29.6 & 18.8 & 85.6 & 35.5 & 85.0 & 39.0 \\
\hline May & 31.2 & 20.4 & 31.6 & 22.4 & 84.5 & 42.5 & 83.4 & 43.7 \\
\hline June & 32.0 & 22.2 & 33.4 & 23.5 & 82.5 & 46.5 & 79.6 & 50.7 \\
\hline July & 33.0 & 21.4 & 33.2 & 25.3 & 79.5 & 49.2 & 84.5 & 53.2 \\
\hline August & 32.5 & 20.2 & 34.6 & 25.0 & 84.0 & 50.0 & 84.9 & 52.1 \\
\hline
\end{tabular}

* Source of this data is Ministry of Agriculture and Land Reclamation, Agriculture Research Center (ARC), Central Management of Agriculture Guideline, Bulletin of Agricultural Meteorological Data.

\section{Statistical analysis:}

Data were tested by analysis of variance according to Gomez and Gomez (1984). Duncan's multiple range test was used for comparison among treatment means (Duncan, 1955).

\section{RESULTS AND DISCUSSION}

\section{A-Effect of phosphorus levels on stem length, plant fresh and dry weight}

Data in Table (3) showed that, stem length, plant fresh and dry weight were highly significant affected by phosphorus fertilization in both growing seasons. The highest phosphorus fertilization level gave the tallest plants and the highest plant fresh and dry weight, whereas $20 \mathrm{~kg}$ phosphorus rate produced the lowest value of each character. The positive effect of the added $P$ could be related to the important role of phosphorus and its vital contribution to several biochemical processes and turn achieved more seeds yield (Marscher, 1986). These results may be due to lack of phosphorus can inhibit the nitrogen uptake (Wieneke, 1995). In the same tendency, (Masui, 1961) found that increasing the phosphorus level promoted vigorous growth of musk melon plants. Also, Olaniyi and Ajibola (2008) indicated that plant height of corchorus plants was increased with the increment of phosphorus level $\left(30 \mathrm{~kg} \mathrm{P} \mathrm{O}_{5} / \mathrm{ha}\right)$. These results are in agreement with that determined by Mady (2009) who clear that phosphorus compound increased plant dry weight of winter squash. 


\section{B-Effect of fruit thinning treatments on plant height, plant fresh and dry weight}

Data presented in Table (3) show that thinning of the first and second fruit (Th. 3) produced the highest values of stem length, plant fresh and dry weight. While, thinning all fruits except the first and second ones (Th. 2) produced the lowest values of each character, and the differences were highly significant in both seasons. These findings are in general agreement with those reported by Metwally (1980) on squash, who showed that plant dry weight was increased resulted in flower removal compared to control. Also, Tabasi et al., (2011) on tomato, who found that stem length parameter was visible in the second generation as affected by fruit thinning treatment.

C-Effect of phosphorus levels and fruit thinning treatments interaction on stem length, plant fresh and dry weight

The effect of the interaction between phosphorus levels and fruit thinning treatments on stem length, plant fresh and dry weight appeared highly significant in both seasons (Table 4). Plants fertilized with $80 \mathrm{~kg}$ $\mathrm{P}_{2} \mathrm{O}_{5} / \mathrm{fed}$. And thinning the first and second fruit (Th. 3) had the highest values of stem length, plant fresh and dry weight. While, the lowest values were obtained from plants fertilized with $20 \mathrm{~kg} \mathrm{P}_{2} \mathrm{O}_{5}$ and thinning all fruits except the first and second ones (Th. 2) in both seasons. On the other hand, the effect of interaction between phosphorus rates and fruit thinning treatments on plant fresh weight was not significant in second season.

Table(3) : Effect of phosphorus fertilizer levels and fruit thinning treatments on stem length, plant fresh and dry weight of summer squash plants during 2012 and 2013 seasons .

\begin{tabular}{|c|c|c|c|c|c|c|}
\hline \multirow{2}{*}{\begin{tabular}{|l|} 
Treatments \\
$\begin{array}{c}\text { A-Phosphorus levels } \\
\left(\mathrm{P}_{2} \mathrm{O}_{5} \mathrm{~kg} / \mathrm{fed} .\right)\end{array}$ \\
\end{tabular}} & \multicolumn{2}{|c|}{ Stem length(cm) } & \multicolumn{2}{|c|}{$\begin{array}{l}\text { Plant fresh weight } \\
\text { (g) }\end{array}$} & \multicolumn{2}{|c|}{ Plant dry weight (g) } \\
\hline & 2012 & 2013 & 2012 & 2013 & 2012 & 2013 \\
\hline 20 & $53.0 \mathrm{c}$ & $55.9 \mathrm{~b}$ & $164.0 \mathrm{~d}$ & $182.6 \mathrm{c}$ & $32.2 \mathrm{c}$ & $39.4 \mathrm{c}$ \\
\hline 40 & $56.8 \mathrm{bc}$ & $61.0 \mathrm{a}$ & $208.2 \mathrm{c}$ & $214.1 \mathrm{~b}$ & $36.1 \mathrm{~b}$ & $50.0 \mathrm{ab}$ \\
\hline 60 & $59.1 \mathrm{ab}$ & $61.3 \mathrm{a}$ & $247.3 \mathrm{~b}$ & $235.8 \mathrm{a}$ & $38.0 \mathrm{ab}$ & $48.1 \mathrm{~b}$ \\
\hline 80 & $61.9 \mathrm{a}$ & $63.0 \mathrm{a}$ & 289.9 a & $244.8 \mathrm{a}$ & $39.7 \mathrm{a}$ & $51.9 a$ \\
\hline F. test & $\star \star *$ & ** & $\star \star$ & $\star \star$ & $\star \star *$ & ** \\
\hline \multicolumn{7}{|l|}{ B-Fruit thinning } \\
\hline Control & $57.2 \mathrm{c}$ & $60.4 \mathrm{c}$ & $234.7 \mathrm{a}$ & $212.4 \mathrm{c}$ & $34.8 \mathrm{c}$ & $45.1 \mathrm{c}$ \\
\hline Th. 1 & $59.4 \mathrm{~b}$ & $61.6 \mathrm{~b}$ & $236.4 \mathrm{a}$ & $233.7 \mathrm{~b}$ & $38.1 \mathrm{~b}$ & $49.1 \mathrm{~b}$ \\
\hline Th. 2 & $54.4 \mathrm{~d}$ & $56.9 \mathrm{~d}$ & $194.7 \mathrm{~b}$ & $173.3 \mathrm{~d}$ & $29.8 \mathrm{~d}$ & $40.2 d$ \\
\hline Th. 3 & $60.1 \mathrm{a}$ & $62.4 \mathrm{a}$ & $243.7 \mathrm{a}$ & $257.8 \mathrm{a}$ & $43.4 \mathrm{a}$ & $55.1 \mathrm{a}$ \\
\hline F. test & $\star * *$ & $* *$ & $\star *$ & $\star * *$ & $\star *$ & $* *$ \\
\hline
\end{tabular}

Values having the same alphabetical letter within each column are not significantly different at the $5 \%$ level, according to Duncan's test

Control (Without thinning), Th.1=Thinning the first fruit, Th.2= Thinning all fruits except the first and second ones and Th.3= Thinning the first and second fruit 
Table(4) :Effect of phosphorus fertilizer levels and fruit thinning treatments interaction on stem length, plant fresh and dry weight of summer squash plants during 2012 and 2013 seasons.

\begin{tabular}{|c|c|c|c|c|c|c|c|}
\hline & \multicolumn{2}{|c|}{ Stem length $(\mathrm{cm})$} & \multicolumn{2}{|c|}{$\begin{array}{l}\text { Plant fresh } \\
\text { weight }(\mathrm{g})\end{array}$} & \multicolumn{2}{|c|}{$\begin{array}{c}\text { Plant dry weight } \\
(\mathrm{g})\end{array}$} \\
\hline $\begin{array}{l}\text { Phosphorus } \\
\text { Levels } \\
\left(\mathrm{P}_{2} \mathrm{O}_{5} \mathrm{~kg}\right. \\
\text { /fed) }\end{array}$ & $\begin{array}{c}\text { Fruit } \\
\text { thinning }\end{array}$ & 2012 & 2013 & 2012 & 2013 & 2012 & 2013 \\
\hline \multirow[t]{4}{*}{ mon } & Control & $52.6 \mathrm{j}$ & $55.6 \mathrm{~h}$ & 163.3 & $188.5 n$ & $32.4 \mathrm{i}$ & $39.5 \mathrm{j}$ \\
\hline & Th. 1 & $54.5 \mathrm{~h}$ & $57.2 \mathrm{~g}$ & 175.2 & $192.9 \mid$ & $34.9 \mathrm{~g}$ & $42.9 \mathrm{i}$ \\
\hline & Th. 2 & $49.6 \mathrm{k}$ & $52.6 \mathrm{i}$ & 131.3 & $126.2 p$ & 25.31 & $30.2 \mathrm{k}$ \\
\hline & Th. 3 & $55.3 \mathrm{~g}$ & $58.3 \mathrm{f}$ & 186.4 & $222.9 \mathrm{i}$ & $36.1 \mathrm{f}$ & $44.8 \mathrm{~g}$ \\
\hline \multirow{4}{*}{40} & Control & $54.3 \mathrm{~h}$ & $61.2 \mathrm{~d}$ & 209.1 & $225.7 \mathrm{~h}$ & $34.9 \mathrm{~g}$ & 47.9 ef \\
\hline & \begin{tabular}{|l|} 
Th. 1 \\
\end{tabular} & $59.2 \mathrm{~d}$ & $62.3 \mathrm{c}$ & 216.2 & $230.2 \mathrm{~g}$ & $36.9 \mathrm{e}$ & $49.7 \mathrm{~d}$ \\
\hline & Th. 2 & $53.3 \mathrm{i}$ & $57.1 \mathrm{~g}$ & 183.3 & 162.10 & $30.3 \mathrm{j}$ & $43.6 \mathrm{~h}$ \\
\hline & Th. 3 & $60.3 c$ & $63.2 \mathrm{~b}$ & 224.2 & $238.2 \mathrm{e}$ & $42.4 \mathrm{~b}$ & $58.8 \mathrm{~b}$ \\
\hline \multirow{4}{*}{60} & Control & $59.4 \mathrm{~d}$ & $61.4 \mathrm{~d}$ & 243.8 & $231.2 \mathrm{f}$ & $38.3 \mathrm{~d}$ & 47.9 ef \\
\hline & Th. 1 & $60.3 \mathrm{c}$ & $62.2 \mathrm{c}$ & 263.3 & $244.9 d$ & $38.4 \mathrm{~d}$ & 48.1 ef \\
\hline & Th. 2 & $56.2 \mathrm{f}$ & $58.3 \mathrm{f}$ & 215.1 & $215.2 \mathrm{j}$ & $35.7 \mathrm{f}$ & $47.5 \mathrm{f}$ \\
\hline & Th. 3 & $60.6 \mathrm{c}$ & $63.6 \mathrm{~b}$ & 266.9 & $251.7 \mathrm{c}$ & $39.6 \mathrm{c}$ & $48.4 \mathrm{e}$ \\
\hline \multirow{4}{*}{80} & Control & $62.3 \mathrm{~b}$ & $63.3 \mathrm{~b}$ & 222.7 & $204.2 \mathrm{k}$ & $33.7 \mathrm{~h}$ & $44.6 \mathrm{~g}$ \\
\hline & Th. 1 & $63.5 \mathrm{a}$ & $64.5 \mathrm{a}$ & 290.7 & $266.9 b$ & $42.2 \mathrm{~b}$ & $55.2 \mathrm{c}$ \\
\hline & Th. 2 & $58.3 \mathrm{e}$ & $59.6 \mathrm{e}$ & 248.9 & $189.6 \mathrm{~m}$ & $27.7 \mathrm{k}$ & $39.4 \mathrm{j}$ \\
\hline & Th. 3 & $63.6 \mathrm{a}$ & $64.6 \mathrm{a}$ & 297.4 & $318.3 \mathrm{a}$ & $55.3 \mathrm{a}$ & $68.5 \mathrm{a}$ \\
\hline \multicolumn{2}{|l|}{ F. test. } & ** & ** & N.S & $\star \star *$ & ** & ** \\
\hline
\end{tabular}

Values having the same alphabetical letter within each column are not significantly different at the $5 \%$ level, according to Duncan's test.

Control (Without thinning), Th.1=Thinning the first fruit, Th.2= Thinning all fruits except the first and second ones and Th.3= Thinning the first and second fruit

\section{D-Effect of phosphorus levels on number of leaves, leaf area and total chlorophyll content}

Data in Table (5) showed that, leaf area/plant and total chlorophyll content were highly significant affected by phosphorus fertilization in both growing seasons. The highest phosphorus fertilization rate $80 \mathrm{~kg} \mathrm{P}_{2} \mathrm{O}_{5} / \mathrm{fed}$. gave the highest leaf area/plant and total chlorophyll content, whereas $20 \mathrm{~kg}$ phosphorus rate produced the lowest value of each character. On the other hand,the effect of phosphorus rates on number of leaves/plant was not significant in both seasons. These reults are in harmony with those obtained by Olaniyi and Ajibola(2008) on cochorus plants, they found that number of leaves were increased with increment of phosphorus treatments $(0,10,20$ and $40 \mathrm{~kg} / \mathrm{ha}$ ). Similar results were reported by Mady (2009) on winter squash as leaf area and chlorophyll $a$ and b content significantly increased with application of phosphorus treatment compared with control. 
Table(5): Effect of phosphorus fertilizer levels and fruit thinning treatments on number of leaves, leaf area and total chlorophyll content of summer squash plants during 2012 and 2013 seasons .

\begin{tabular}{|c|c|c|c|c|c|c|}
\hline \multirow{2}{*}{$\begin{array}{l}\text { Treatments } \\
\text { A-Phosphorus levels } \\
\left(\mathrm{P}_{2} \mathrm{O}_{5} \mathrm{~kg} / \mathrm{fed}\right)\end{array}$} & \multicolumn{2}{|c|}{ No. of leaves/plant } & \multicolumn{2}{|c|}{$\begin{array}{c}\text { Leaf area/ plant } \\
\left(\mathrm{cm}^{2}\right)\end{array}$} & \multicolumn{2}{|c|}{ Total chlorophyll } \\
\hline & 2012 & 2013 & 2012 & 2013 & 2012 & 2013 \\
\hline 20 & 18.3 & 19.2 & $1237.3 \mathrm{~d}$ & $1365.5 \mathrm{~d}$ & $29.2 \mathrm{a}$ & 30.1 \\
\hline 40 & 18.7 & 21.6 & $1595.5 \mathrm{c}$ & $1513.1 \mathrm{c}$ & $29.3 \mathrm{a}$ & 29.6 \\
\hline 60 & 19.9 & 22.1 & $1723.2 \mathrm{~b}$ & $1854.1 \mathrm{~b}$ & $30.1 \mathrm{a}$ & 30.9 \\
\hline 80 & 21.3 & 23.2 & $1955.9 \mathrm{a}$ & $2152.4 \mathrm{a}$ & $29.7 \mathrm{a}$ & 30.9 \\
\hline F. test & N.S & N.S & $\star \star$ & ** & * & N.S \\
\hline \multicolumn{7}{|l|}{ B-Fruit thinning } \\
\hline Control & $19.5 \mathrm{c}$ & $21.2 \mathrm{c}$ & $1497.0 \mathrm{c}$ & $1638.4 \mathrm{c}$ & $29.4 \mathrm{C}$ & $30.1 \mathrm{c}$ \\
\hline Th. 1 & $20.0 \mathrm{~b}$ & $21.8 \mathrm{~b}$ & $1768.4 \mathrm{~b}$ & $1821.5 \mathrm{~b}$ & $30.7 \mathrm{~b}$ & $31.4 \mathrm{~b}$ \\
\hline Th. 2 & $18.3 \mathrm{~d}$ & $20.7 d$ & $1407.8 \mathrm{~d}$ & $1472.4 \mathrm{~d}$ & $26.7 \mathrm{~d}$ & $27.4 \mathrm{~d}$ \\
\hline Th. 3 & $20.3 \mathrm{a}$ & $22.3 \mathrm{a}$ & $1838.6 \mathrm{a}$ & $1952.7 \mathrm{a}$ & $31.4 \mathrm{a}$ & $32.7 \mathrm{a}$ \\
\hline F. test & $\star *$ & $* *$ & ** & ** & ** & $\star *$ \\
\hline
\end{tabular}

Values having the same alphabetical letter within each column are not significantly different at the $5 \%$ level, according to Duncan's test.

${ }^{* \star}, *$ and N.S indicate significant differences at $P<0.01, P<0.05$ and not significant, respectively according to $F$. test.

Control (Without thinning), Th.1=Thinning the first fruit, Th.2= Thinning all fruits except the first and second ones and Th.3= Thinning the first and second fruit

\section{E-Effect of fruit thinning treatments on number of leaves, leaf area and total chlorophyll content}

Data presented in Table (5), showed that thinning the first and second fruit (Th. 3) produced the highest values of number of leaves/plant, leaf area/plant and total chlorophyll content. While, thinning all fruit except the first and second ones (Th. 2) produced the lowest values of each character, and the differences were highly significant in both seasons. These findings are in general agreement with those reported by Stephenson et al.,(1988) on squash and El-Keblawy and Lovett-Douset (1996) on cantaloupe, they found that fruit removal increased total number of leaves.

Also, these results are in agreement with that determined by Wien et al.,(1973) on beans, who reported that flower removal caused slightly higher of leaf area.

F-Effect of phosphorus levels and fruit thinning treatments interaction on number of leaves, leaf area and total chlorophyll content:

The effect of the interaction between phosphorus levels and fruit thinning treatments on number of leaves/plant, leaf area/plant and total chlorophyll appeared highly significant in both seasons (Table 6). The treatments thinning the first and second fruit (Th.3) had the highest number of leaves/plant, leaf area/plant and total chlorophyll content when phosphorus rate was $80 \mathrm{~kg} \mathrm{P}_{2} \mathrm{O}_{5} / \mathrm{fed}$. While, the lowest values were obtained from plants fertilized with $20 \mathrm{~kg} \mathrm{P}_{2} \mathrm{O}_{5}$ and thinning all fruits except the first and second ones (Th.2) in both seasons. 
Table (6): Effect of phosphorus fertilizer levels and fruit thinning treatments interaction on number of leaves, leaf area and total chlorophyll content of summer squash plants during 2012 and 2013 seasons.

\begin{tabular}{|c|c|c|c|c|c|c|c|}
\hline Treatments & & No. of le & es/plant & Leaf area/ & lant $\left(\mathrm{cm}^{2}\right)$ & Total & ophyll \\
\hline $\begin{array}{l}\text { Phosphorus } \\
\text { levels } \\
\left(\mathrm{P}_{2} \mathrm{O}_{5}\right. \\
\mathrm{kg} / \mathrm{fed})\end{array}$ & $\begin{array}{c}\text { Fruit } \\
\text { thinning }\end{array}$ & 2012 & 2013 & 2012 & 2013 & 2012 & 2013 \\
\hline & Control & $18.2 \mathrm{~h}$ & 19.2 ef & $1119.4 \mathrm{~m}$ & 1264.10 & $28.4 \mathrm{~h}$ & $29.6 \mathrm{~h}$ \\
\hline २० & Th. 1 & $18.6 \mathrm{~g}$ & 19.3 ef & $1439.2 \mathrm{k}$ & $1396.9 n$ & $30.1 \mathrm{f}$ & $31.1 \mathrm{f}$ \\
\hline 20 & Th. 2 & $17.6 \mathrm{i}$ & $18.1 \mathrm{f}$ & $948.1 \mathrm{n}$ & $1102.6 p$ & $27.1 \mathrm{i}$ & $27.5 \mathrm{j}$ \\
\hline & Th. 3 & $18.6 \mathrm{~g}$ & $20.2 \mathrm{de}$ & $1442.3 \mathrm{j}$ & $1698.2 \mathrm{~h}$ & $31.2 \mathrm{c}$ & $32.2 \mathrm{c}$ \\
\hline & Control & $18.6 \mathrm{~g}$ & $20.2 \mathrm{de}$ & $1437.5 \mathrm{k}$ & $1463.5 \mathrm{k}$ & $30.1 \mathrm{f}$ & $29.6 \mathrm{~h}$ \\
\hline & Th. 1 & $19.2 \mathrm{f}$ & $22.3 \mathrm{bc}$ & $1788.1 \mathrm{~g}$ & $1566.1 \mathrm{j}$ & $30.9 \mathrm{~d}$ & 31.2 ef \\
\hline 40 & Th. 2 & $17.3 \mathrm{j}$ & $21.3 \mathrm{~cd}$ & $\begin{array}{l}1361.7 I \\
\end{array}$ & $1404.6 \mathrm{~m}$ & $24.9 \mathrm{k}$ & $25.1 \mathrm{k}$ \\
\hline & Th. 3 & $19.6 \mathrm{e}$ & $22.4 \mathrm{bc}$ & $1794.5 \mathrm{f}$ & $1618.1 \mathrm{i}$ & $31.2 \mathrm{c}$ & $32.5 \mathrm{bc}$ \\
\hline & Control & $19.6 \mathrm{e}$ & $22.2 \mathrm{bc}$ & $1588.4 \mathrm{~h}$ & $1784.8 \mathrm{~g}$ & $29.6 \mathrm{~g}$ & $30.9 \mathrm{f}$ \\
\hline 60 & Th. 1 & $20.6 \mathrm{c}$ & $22.3 \mathrm{bc}$ & $1788.5 \mathrm{~g}$ & $2033.7 \mathrm{e}$ & $30.8 \mathrm{e}$ & $31.5 \mathrm{de}$ \\
\hline 0 & Th. 2 & $18.6 \mathrm{~g}$ & $21.1 \mathrm{~cd}$ & $1500.8 \mathrm{i}$ & 1444.31 & $28.4 \mathrm{~h}$ & $28.5 \mathrm{i}$ \\
\hline & Th. 3 & $20.6 \mathrm{c}$ & $22.6 \mathrm{bc}$ & 2014.9 c & $2135.7 \mathrm{c}$ & $31.5 b$ & $32.7 b$ \\
\hline & Control & $21.6 \mathrm{~b}$ & $23.2 \mathrm{ab}$ & $1842.7 \mathrm{~d}$ & $2041.2 \mathrm{~d}$ & $29.6 \mathrm{~g}$ & $30.3 \mathrm{~g}$ \\
\hline 80 & Th. 1 & $21.6 b$ & $23.3 \mathrm{ab}$ & 2057.8 b & $2289.3 \mathrm{~b}$ & $30.9 d$ & $31.6 \mathrm{~d}$ \\
\hline 00 & Th. 2 & $19.8 d$ & $22.3 b c$ & $1820.5 \mathrm{e}$ & $1938.2 \mathrm{f}$ & $26.4 \mathrm{j}$ & $28.4 \mathrm{i}$ \\
\hline & Th. 3 & $22.3 \mathrm{a}$ & $24.1 \mathrm{a}$ & $2102.5 \mathrm{a}$ & $2340.9 a$ & $31.8 \mathrm{a}$ & $31.6 \mathrm{a}$ \\
\hline$F$. & & 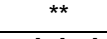 & 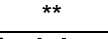 & $\star *$ & 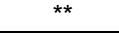 & 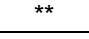 & + \\
\hline
\end{tabular}

Values having the same alphabetical letter within each column are not significantly different at the $5 \%$ level, according to Duncan's test.

Control (Without thinning), Th.1=Thinning the first fruit, Th.2= Thinning all fruits except the first and second ones and Th.3= Thinning the first and second fruit.

\section{REFERENCES}

Black, C.A. (1965). Methods of Soil Analysis. Amer. Soc. Agron. Inc. Madison, Wisconsin, USA.

Cottenie,A.;M.Verloo;M.Velghe and R.Camerly (1982). Chemical analysis of plant and soil. Laboratory of Analytical and Agrochemistry, State Univ.Ghent, Belgium. Chapter 2, 3, pp.14-54.

Duncan, B.D.(1955). Multiple range and multiple, F.tests. Biometrics, 11:1-42.

EL-Keblawy and Lovett-Douset (1996a). Resource Re-Allocation following fruit removal in cucurbits: patterns in cantaloupe melons. New phytologist, 134 (3): 413-422.

EL-Keblawy and Lovett-Douset (1996b). Resource Re-Allocation following fruit removal in cucurbits: patterns in two varieties of squash. New phytologist.,133:583-593.

Gomez, K. A. and A. A. Gomez (1984). Statistical Procedures for Agricultural Research. John Willey and Sons. Inc. York.

Jackson, M. L. (1967). "Soil Chemical Analysis". Printico-Hall of India, New Delhi.

Koller, H. R. (1972) . Leaf area weight relation ships in the soybean canopy .American Soci. of Agro. Alliance of crop, soil and Environmental . Sci.Soci.vol.12 No.2 P. 180-183. 
Mady, M.A. (2009). Effect of some phosphorus compounds as seed-soaking materials on winter squash (Cucurbita pepo L.) plants. J. Agric. Sci Mansoura Univ., 34(6): 6747-6759.

Marschner, H. (1986). Mineral nutritional in higher plants. Academic Press, Harcourt Brace, Jovanovish Publisher, pp. 674.

Masui, M. (1961). Studies on the absorption of nutrient elemants in muskmelon.1-on nitrogen and phosphorus levels .Bull. LNEAC 1960 (9): 129-130.(C.F., Hort. Abst.31, 2405).

Metwally, E .I. A. (1980). Growth and yield of squash (Cucurbita pepo L.)as affected by planting data and some defloration teratments. M.Sc. Thesis, Fac. Agric., Tanta Unv. Egypt,pp.77.

Moran, R. and D. Porath (1982). Chlorophyll determination in intact tissue using N, N dimethyle for mamide Plant Physiol.,65:478-479.

Mulins, G. (2009). Phosphorus, Agriculture \& The Environment Professor and Extension Specialist, Nutrient Management, Department of Crop and Soil Environmental Sciences, Virginia Tech May. 424-029

Olaniyi, J.O.and A.T.Ajibola (2008).Growth and yield performance of Corchorus olitorus varieties as affected by nitrogen and phosphorus fertilizers application. American-Eurasian J. of Sustainable Agri., 2(3):234-241.

Page, A.L.; R.H. Miller and D.R. Keeney (1982). "Methods of Soil Analysis". Part II- Chemical and microbiological properties. A. S. A. Madison Wisc., USA.

Starnes, D. L; P. Padmanabhan and S.V.Sahi (2008). Effect of P sources on growth, $P$ accumulation and activitiea of phytase and acid phosphatases in two cultivars of annual ryegrass (Lolium multiflorum $\mathrm{L}$. ) plant physiology and Biochemistry, 46:580-589.

Stephenson A.G; B.Devlin and J.B. Horton (1988). The effect of seed number and prior fruit dominance on the pattern of fruit production in Cucurbita pepo (Zucchini Squash ). Annals of Botany, 62:653-661.

Tabasi, A; H. Nemati; A.Tehranifar and M. Akbari (2011).The effects of shrub pruning and fruit thinning on seed germination and seedling of tomato in the next generation (Lycopersicon esculentum Mill) J. Biol. Envron. Sci., 5 (14):105-110.

Wien, H.C.; R. F. Sandsted and D. H. Wallace (1973). The influence of flower removal on growth and seed yield of (Phaseolus vulgaris L.). J. Amer. Soc. Hort. Sci., 98 (1):45-49.

Wieneke, J. (1995). Altered Influx/Efflux Relations of Nitrate in Roots due to Nutrient Stress. I. Effect of Phosphorus and Zinc Deprivation. J. Plant Nutrition, 18 (8): 1547-1561. 


$$
\begin{aligned}
& \text { تأثير التسميد الفوسفاتى وخف الثمار على إنتاج تقاوى قرع الكوسة }
\end{aligned}
$$

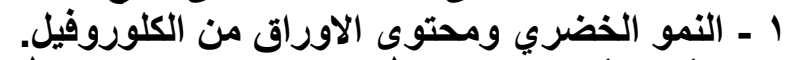

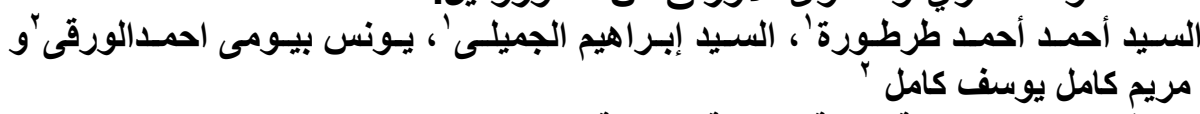

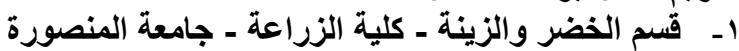

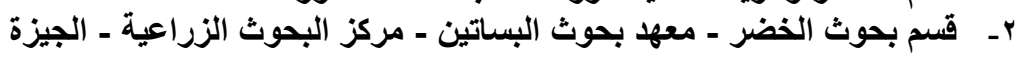

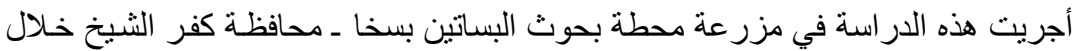

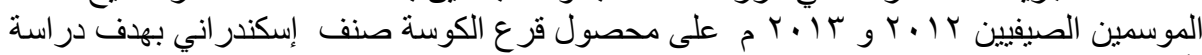

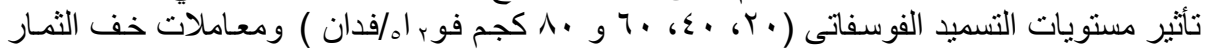

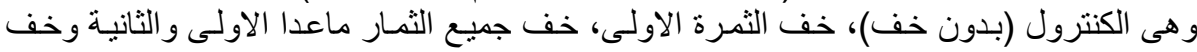

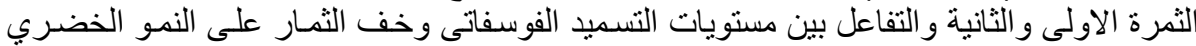

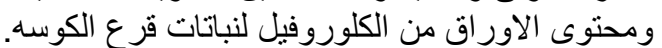
ويمكن تلخيص الهم النتائج المتحصل عليها لثان كالآني:-

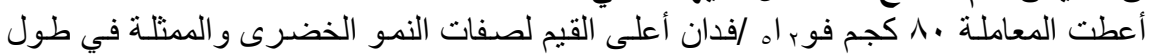

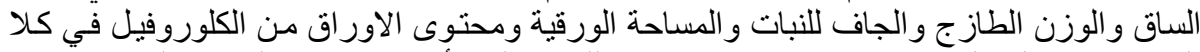

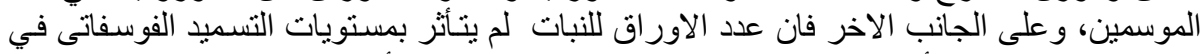

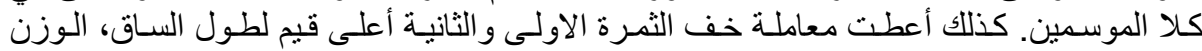

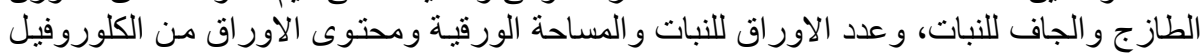

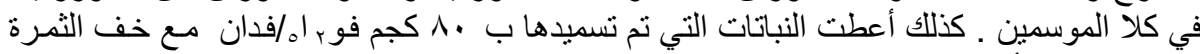

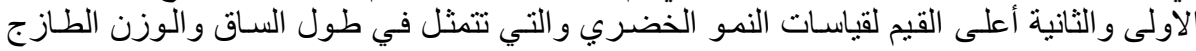

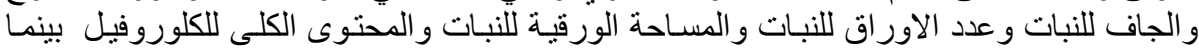

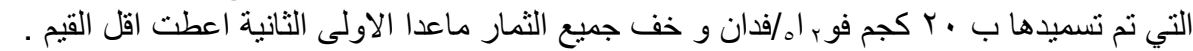

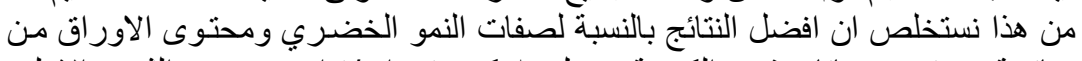
الكلوروفيل ناتجة من تسميد نباتات قرع الكوسة بمعدل •1 كجم فو ب اه /فدان مع خف النف الثمرة الاولى النى 